\title{
Yield Analysis of Oilseed Crops under Front Line Demonstration Programmes in Medium and High Land Farming Situations of Birbhum District
}

\author{
Prabuddha Ray ${ }^{1 *}$, Subrata Mandal ${ }^{2}$, Sourav Mondal ${ }^{3}$ and Palash Ankure ${ }^{4}$
}

\begin{abstract}
${ }^{1}$ Subject Matter Specialist (Agricultural Extension), Rathindra Krishi Vigyan Kendra, Palli Siksha Bhavana (Institute of Agriculture), Visva-Bharati, Sriniketan, West Bengal, India

${ }^{2}$ Programme Coordinator (Officiating) and Subject Matter Specialist (Agronomy), Rathindra Krishi Vigyan Kendra, Palli Siksha Bhavana (Institute of Agriculture), Visva-Bharati, Sriniketan, West Bengal, India

${ }^{3}$ Subject Matter Specialist (Plant Protection), Rathindra Krishi Vigyan Kendra, Palli Siksha Bhavana (Institute of Agriculture), Visva-Bharati, Sriniketan, West Bengal, India

${ }^{4}$ Programme Assistant (Farm Manager), Rathindra Krishi Vigyan Kendra, Palli Siksha Bhavana (Institute of Agriculture), VisvaBharati, Sriniketan, West Bengal, India
\end{abstract}

*Corresponding author: prabuddha_ray1@rediffmail.com (ORCID ID: 0000-0001-9283-275X)

Paper No. 842

Received: $22-01-2020$

Revised: 13-04-2020

Accepted: 24-05-2020

\begin{abstract}
The present study is based on the analysis of yield obtained from the Front Line Demonstration Programmes (as Demonstration is one of the most time-tested method in Extension Education) on Oilseed Crops (viz. Sesame, Rapeseed and Mustard and Linseed) organized by the Rathindra KVK in Medium and High Land Farming Situations of Birbhum District and comparative yield analysis over the Birbhum District Average and the West Bengal State Average. The study revealed that the FLD Programme on Sesame; Rapeseed and Mustard and Linseed produced an average yield higher than the Birbhum District Average and also higher than the State Average consistently over the years (as mentioned in the Paper) with the one and only exception in the Rabi Season of 2017-18, when the State Average Yield of Rapeseed and Mustard was higher than the Average yield achieved in the Rathindra KVK FLD Progtramme. The Study also pointed out another important fact that the Birbhum District average yield of Sesame; Rapeseed and Mustard and Linseed were consistently and significantly lower than the state Average with only bright and positive exception in the case of Linseed (the Birbhum District Average Yield of Linseed was higher than that of the state average in both the years of 2016-17 and 2017-18) showing a huge un-tapped potential for production of Linseed in the District. The study further showed us that the positive yield gap achieved by the FLD Programme on Sesame, Rapeseed and Mustard and Linseed over Birbhum District Average Yield and at same time over the West Bengal State Average Yield was consistently and significantly higher in the specified time period with the only exception in the Rabi Season of 2017-18, when the State Average Yield of Rapeseed and Mustard was slightly higher (by $0.25 \mathrm{q} / \mathrm{ha}$ ) over the average yield obtained from Rathindra KVK FLD Programme.
\end{abstract}

\section{Highlights}

(0 The present study revealed that the FLD Programme on Sesame; Rapeseed and Mustard and Linseed produced an average yield significantly higher than the Birbhum District Average and also higher than the State Average (with very few exceptions) consistently over the years.

Keywords: Front Line Demonstration, Yield, Yield Gap, Oilseed Crops

Demonstration is one of the time tested methods in Agricultural Extension to assess the production potential of a product or technology or service in the real life situation as well as to disseminate that product or technology or service among the interested stakeholders through the use of "Seeing 
is believing" Principle. Demonstration is a group extension method refined from the first organized form by Dr. Seaman Knapp in Community Demonstration Farm in Texas, USA in 1903 AD and first organized Farm Demonstration Programme on Cotton Boll Weevil control measures through engaging 24 special agents for supplementing the efforts of Dr. Knapp in 1904 AD (Dahama and Bhatnagar 1999). One of the advanced forms of this Demonstration Method of Group Extension is the Front Line Demonstration (FLD) used basically for improved products, technologies and or services through organization of a well structured pre-planned extension programme involving planning, execution, monitoring and evaluation sub-components.

Yield is one of the major assessment parameters of a majority of Front Line Demonstration Programmes in Agriculture and related Sectors. Yield is the Units of production produced from a specified production unit in a specific time frame. So, yield analysis of any FLD Programme is essential to judge the success of the programme.

The Rathindra Krishi Vigyan Kendra, Palli Siksha Bhavana (Institute of Agriculture), Visva-Bharati, Sriniketan, Birbhum District tried to assess and disseminate the improved High Yielding Varieties and assorted modern package of production technologies of Oilseed Crops viz. Sesame, Rapeseed and Mustard and Linseed in its mandated district i.e. Birbhum in the state of West Bengal through organization of FLD Programmes for the last couple of years. The reasons of choosing these three crops are based on socio-situational factors as well as potential analysis and importance of these crops in the overall oilseed production scenario in India, West Bengal and most importantly in the Birbhum District as discussed later.

In the Indian context, Sesame is one of the earliest domesticated plants of the country and an important edible oilseed crop cultivated throughout the world. India ranks second in Sesame production and first in area by contributing 23.2 per cent and 13.1 per cent of the world production and area respectively (Kithan and Singh, 2017). In India, Sesame is cultivated in an area of 16.66 lakh hectares with production of 6.75 lakh tonnes and productivity of $4.05 \mathrm{q} /$ ha (ICAR, 2015). In 2015-16, the area, production and yield of Sesame was 19,50,880 ha;
8,50,070 MT and $4.36 \mathrm{q} /$ ha respectively (Govt. of India, 2017). Being short duration in nature, Sesame is an ideal crop for cultivation in rice fallows (Chauhan et al. 2016).

In India, Rapeseed and Mustard are the most important oilseed crops grown next to Groundnut. In 2015-16, the area, production and yield of Rapeseed and Mustard was 57,45,520 ha; 67,96,720 MT and 11.83 q / ha respectively (Govt. of India, 2017).

Linseed or Flax is one of the important Rabi oilseed crops. In India, Linseed occupies an area of 3.38 lakh ha with a production of 1.47 lakh tonnes and a productivity of $435 \mathrm{~kg} / \mathrm{ha}$ (ICAR, 2014). In 201516 , the area, production and yield of Linseed was 2,62,860 ha; 1,25,490 MT and $4.77 \mathrm{q} /$ ha respectively (Govt. of India 2017).

\section{Methodology}

The Rathindra Krishi Vigyan Kendra has selected the Sesame for Front Line Demonstration Programme in the Summer Season since the Year of 2013 and from the year of 2017 for both Summer and Kharif Season mainly because of the fact that there is a large tract of Rice-Fallow which can be effectively brought under a productive cultivation practices.

The choice of Sesame crop by the Rathindra KVK has been mainly caused by the factor of dual advantage of crop diversification and sustainable production practices through utilizing resource conservation technologies (as crop diversification is one of the major thrust areas of the Rathindra KVK and promoting conservation agricultural practices by utilizing the residual moisture of rice crop for growing the Sesame Crop). According to Govt. of India (2015) and Govt. of India (2017a), from the year of 2008 to the year of 2011, the total Rice-Fallow of Birbhum District was 2.876 lakh hectares. The demonstration programme on Sesame production in Summer Seasons can open up a new avenue before the Birbhum District farming community to productively utilize the potential of this huge Rice-Fallow area of the District. Iqbal et al. (2018) pointed out that though in India there was a huge production of Sesame still Indian productivity (yield) of Sesame is low compared to other Sesame producing countries of the World. So, while emphasizing on the favourable climatic 
and situational conditions of production and remunerative price of the crop, one of the simplest approach to increase horizontal expansion of the Sesame crop production is to boost up productivity of the crop (Iqbal et al. 2018).

Another factor behind choosing the Sesame Crop for FLD Programme was that the crop was second most important Oilseed crop of Birbhum with an area of 5,066 hectares of land (13.79 per cent of the total land under Oilseed cultivation in Birbhum District) with a production of 3,734 Tonnes (11.24 per cent of the total Oilseed production of Birbhum District) in 2012-13 (Govt. of India 2020). However, the Birbhum District Average yield of Sesame is $7.40 \mathrm{q} /$ ha whereas the state Average Yield of West Bengal is $9.20 \mathrm{q} /$ ha in 2012-13 (Govt. of India, 2020). So bridging this yield gap and achieve higher levels of yield through introduction of High Yielding Varieties and assorted improved Package of Practices for Sesame production was another factor behind the choice of the crop for the FLD Programme.

The Rapeseed and Mustard is the most prominent Oilseed crop of Birbhum with an area of 33,497 hectares of land (86.02 per cent of the total land under Oilseed cultivation in Birbhum District) with a production of 34,451 Tonnes (89.61 per cent of the total Oilseed production of Birbhum District) in 2013-14. However, the Birbhum District Average yield of Rapeseed and Mustard is $10.3 \mathrm{q} /$ ha whereas the state Average Yield of West Bengal is $10.7 \mathrm{q} /$ ha in 2013-14 (Govt. of India 2020). The main objective behind choosing the Rapeseed and Mustard for FLD Programme by the Rathindra KVK is to close this yield gap and achieve higher levels of yield through introduction of High Yielding Varieties and supplementary Technological Package of Practices.

Linseed is one of the minor Oilseed crops of Birbhum District as far as area under cultivation (with a minute area of 289 hectares i.e. 00.72 per cent of the total area under Oilseed Crops in Birbhum District in 2014-15) and production (with a small quantity of produce to tune of 71.00 Tonnes i.e. 00.26 per cent of the total Oilseed Production of Birbhum District in 2014-15) (Govt. of India 2020) are concerned. In Birbhum District the average Linseed Yield was $2.50 \mathrm{q} /$ ha whereas the state of West Bengal average was $3.60 \mathrm{q} /$ ha in 2014-15
(Govt. of India 2020). In this background in mind, the Rathindra Krishi Vigyan Kendra started the FLD Programme on Linseed in 2015-16, mainly emphasizing on increasing the popularity of the production of this crop through introduction of improved High Yielding Varieties, technological package of practices etc. This oilseed crop is chosen for demonstration purpose as Linseed Oil has a huge domestic demand as it can be used both for edible and non-edible purposes. Linseed contains 35 to 45 per cent oil. It is grown either for the oil from the seed or fibre from the stem. Edible Linseed oil is used for human consumption and contains A-Linolenic Acid (ALA), a polyunsaturated fatty acid that has nutritional and health benefits. Apart from ALA, Linseed is widely used as nutritional and functional food as it also contains Omega-3 Fatty Acid. The Linseed oil is an important ingredient in the manufacturing process of paint, varnish, printing ink and linoleum.

These three crops viz. Sesame, Rapeseed and Mustard and Linseed were demonstrated through organization of Front Line Demonstration Programmes in the medium and upland farming situations of Birbhum District by the Rathindrta KVK. Sesame was grown as summer crop (in 2017 also as Kharif crop) whereas Rapeseed and Mustard and Linseed were grown as Rabi crops.

\section{The present study is being undertaken with the following objectives}

1. To compare the average yield of Sesame; Rapeseed and Mustard and Linseed obtained from the Rathindra KVK FLD, Birbhum District and West Bengal State and

2. To assess the Average Yield Gaps with respect to Rathindra KVK FLD Average Yield over Birbhum District Average Yield and West Bengal State Average Yield.

\section{FINDINGS AND DISCUSSION}

The following data (Table 1 and Fig. 1) obtained from the analysis of the FLD Programme on Sesame organized by the Rathindra KVK as well as Birbhum District Average Yield and West Bengal State Average Yield, clearly showed us that the FLD Programme organized by the Rathindra KVK produced an average yield higher than the Brbhum District Average and also higher than the State 
Average consistently over the years i.e. from 2013 to 2017. However, here an interesting point is to note down that except the summer season of 2017, the Birbhum District average yield was consistently and significantly lower than the state Average.

Table 1: Comparison of Yield of Crop - Sesame

\begin{tabular}{|c|c|c|c|c|c|}
\hline \multirow[b]{2}{*}{$\begin{array}{l}\text { Sl. } \\
\text { No. }\end{array}$} & \multirow[b]{2}{*}{ Year } & \multirow[b]{2}{*}{ Season } & \multicolumn{3}{|c|}{ Average Yield (q / ha) } \\
\hline & & & $\begin{array}{l}\text { Rathindra } \\
\text { KVK FLD* }\end{array}$ & $\begin{array}{l}\text { Birbhum } \\
\text { District** }\end{array}$ & $\begin{array}{l}\text { State } \\
\text { of West } \\
\text { Bengal }^{* * *}\end{array}$ \\
\hline 1 & 2013 & Summer & 10.20 & 07.40 & 08.24 \\
\hline 2 & 2014 & Summer & 10.50 & 07.60 & 09.27 \\
\hline 3 & 2015 & Summer & 10.50 & 07.10 & 09.33 \\
\hline 4 & 2016 & Summer & 10.47 & 06.40 & 09.24 \\
\hline 5 & 2017 & Summer & 12.20 & 10.40 & 09.77 \\
\hline 5 & 2017 & Kharif & 10.25 & $10.25^{\sharp}$ & 06.83 \\
\hline
\end{tabular}

N. B.: - * Source: - Annual Reports of Rathindra KVK

** and *** Source: Crop Production Statistics Information System, Special Data Dissemination Standard Division, Directorate of Economics and Statistics, Ministry of Agriculture and Farmers' Welfare, Govt. of India (Internet Source: - aps.dac.gov.in/APY/).

\# New Introduction in Birbhum District by the Rathindra KVK.

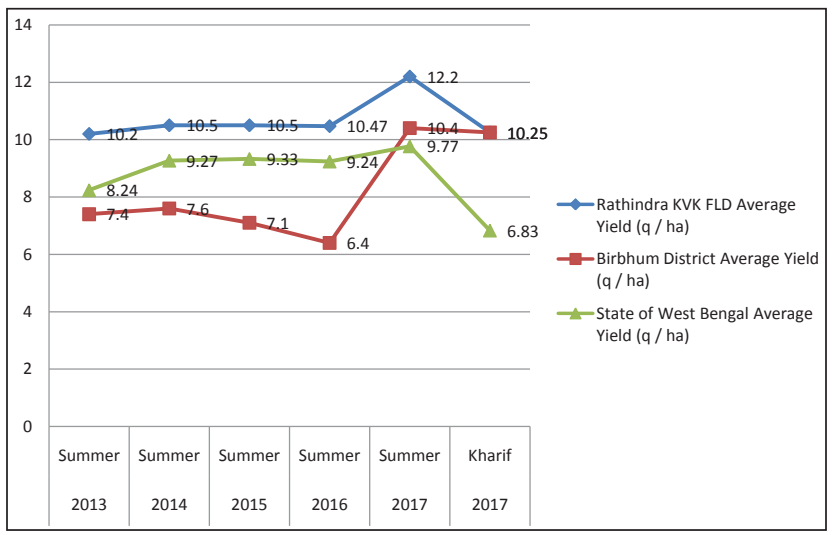

Fig. 1: Comparison of Yield of Crop - Sesame

The Table 2 pointed out that the positive yield gap achieved by the Rathindra KVK FLD Programme on Sesame over Birbhum District Average Yield was consistently higher than the positive yield gap achieved by the FLD Programme over the state of West Bengal Average Yield over the time frame as mentioned except for the Summer Season of 2017.

Observation from the following data (Table 3 and Fig. 2) revealed that the FLD Programme on Rapeseed and Mustard organized by the Rathindra KVK produced consistently higher yields than both the Birbhum District Average Yield and West Bengal State Average Yield, over the specified time period i.e. from 2014-15 to 2017-18, except in the Rabi Season of 2017-18, when the State Average Yield of Rapeseed and Mustard was higher than the Average yield achieved in the Rathindra KVK FLD Progtramme. However, it is pertinent to mention that here an interesting point is to note down that the Birbhum District average yield of Rapeseed and Mustard was way below the state Average over this time frame.

Table 2: Yield Gap of Rathindra KVK FLD Average Yield* over Birbhum District Average Yield and West

Bengal State Average Yield of Crop - Sesame

\begin{tabular}{lllll}
\hline & & & \multicolumn{2}{c}{ Yield Gap (q/ha) (+/ -) } \\
\cline { 3 - 4 } S1. & Year & Season & $\begin{array}{l}\text { Over Birbhum } \\
\text { District Average } \\
\text { Yield** }\end{array}$ & $\begin{array}{l}\text { Over West Bengal } \\
\text { State Average } \\
\text { Yield*** }\end{array}$ \\
\hline 1 & 2013 & Summer & $02.80(+)$ & $01.96(+)$ \\
2 & 2014 & Summer & $02.90(+)$ & $01.23(+)$ \\
3 & 2015 & Summer & $03.40(+)$ & $01.17(+)$ \\
4 & 2016 & Summer & $04.07(+)$ & $01.23(+)$ \\
5 & 2017 & Summer & $01.80(+)$ & $02.43(+)$ \\
5 & 2017 & Kharif & Not Applicable & $03.42(+)$ \\
\hline
\end{tabular}

N. B.: - * Source: - Annual Reports of Rathindra KVK

** and *** Source: Crop Production Statistics Information System, Special Data Dissemination Standard Division, Directorate of Economics and Statistics, Ministry of Agriculture and Farmers' Welfare, Govt. of India (Internet Source: - aps.dac.gov.in/APY/).

\# New Introduction in Birbhum District by the Rathindra KVK.

Table 3: Comparison of Yield of Crop - Rapeseed and Mustard

\begin{tabular}{|c|c|c|c|c|c|}
\hline \multirow{2}{*}{$\begin{array}{l}\text { Sl. } \\
\text { No. }\end{array}$} & \multirow[b]{2}{*}{ Year } & \multirow[b]{2}{*}{ Season } & \multicolumn{3}{|c|}{ Average Yield (q / ha) } \\
\hline & & & $\begin{array}{l}\text { Rathindra } \\
\text { KVK FLD* }\end{array}$ & $\begin{array}{l}\text { Birbhum } \\
\text { District** }\end{array}$ & $\begin{array}{l}\text { State of West } \\
\text { Bengal }^{* * *}\end{array}$ \\
\hline 1 & 2014-15 & Rabi & 11.80 & 08.30 & 10.70 \\
\hline 2 & $2015-16$ & Rabi & 11.92 & 08.90 & 10.70 \\
\hline 3 & 2016-17 & Rabi & 12.02 & 09.20 & 10.80 \\
\hline 4 & 2017-18 & Rabi & 11.75 & 09.70 & 12.00 \\
\hline
\end{tabular}

N. B.: - * Source: - Annual Reports of Rathindra KVK

** and *** Source: Crop Production Statistics Information System, Special Data Dissemination Standard Division, Directorate of Economics and Statistics, Ministry of Agriculture and Farmers' Welfare, Govt. of India (Internet Source: - aps.dac.gov.in/APY). 


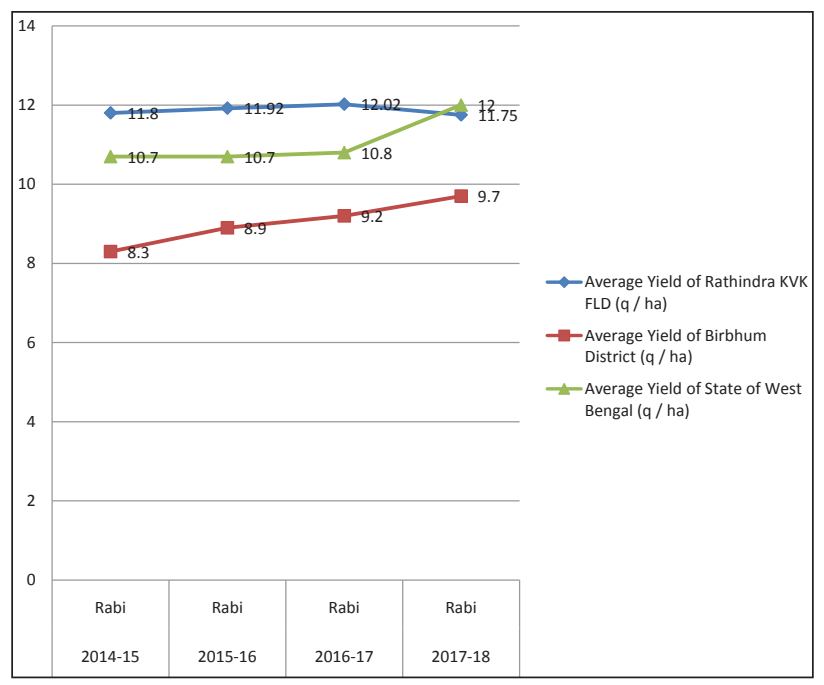

Fig. 2: Comparison of Yield of Crop - Rapeseed and Mustard

The analysis of the under noted Table 4 showed us that the positive yield gap achieved by the Rathindra KVK FLD Programme on Rapeseed and Mustard over Birbhum District Average Yield was consistently higher than the positive yield gap achieved by the FLD Programme over the state of West Bengal Average Yield over the time period from 2014-15 to 2016-17; while in the Rabi Season of 2017-18, though the FLD Programme gave a positive yield gap of impressive $2.05 \mathrm{q} /$ ha over the Birbhum District Average Yield, still the State Average Yield of Rapeseed and Mustard was slightly higher (by $0.25 \mathrm{q} / \mathrm{ha}$ ) over the average yield obtained from Rathindra KVK FLD Programme.

Table 4: Yield Gap of Rathindra KVK FLD Average Yield* over Birbhum District Average Yield and West Bengal State Average Yield of Crop - Rapeseed and

Mustard

\begin{tabular}{lllll}
\hline \multirow{2}{*}{$\begin{array}{l}\text { S1. } \\
\text { No. }\end{array}$} & \multirow{2}{*}{ Year } & Season & \multicolumn{2}{c}{ Yield Gap (q / ha) (+ / -) } \\
\cline { 3 - 5 } & & $\begin{array}{l}\text { Over Birbhum } \\
\text { District Average } \\
\text { Yield** }\end{array}$ & $\begin{array}{l}\text { Over West } \\
\text { Bengal State } \\
\text { Average Yield*** }\end{array}$ \\
\hline 1 & $2014-15$ & Rabi & $03.50(+)$ & $01.10(+)$ \\
2 & $2015-16$ & Rabi & $03.02(+)$ & $01.22(+)$ \\
3 & $2016-17$ & Rabi & $02.82(+)$ & $01.22(+)$ \\
4 & $2017-18$ & Rabi & $02.05(+)$ & $00.25(-)$ \\
\hline
\end{tabular}

N. B.: - * Source: - Annual Reports of Rathindra KVK

** and ${ }^{* * *}$ Source: Crop Production Statistics Information System, Special Data Dissemination Standard Division, Directorate of Economics and Statistics, Ministry of Agriculture and Farmers' Welfare, Govt. of India (Internet Source: - aps.dac.gov.in/APY).
Interpretation of the following data (Table 5 and Fig. 3) on the FLD Programme on Linseed organized by the Rathindra KVK as well as Birbhum District Average Yield and West Bengal State Average Yield, delineated that the FLD Programme on Linseed organized by the Rathindra KVK produced an average yield way higher than the Brbhum District Average as well as also significantly higher than the State Average consistently over the years i.e. from 2015-16 to 2017-18 pointing towards a huge potential in Linseed cultivation in Birbhum District as far as yield component is concerned. However, here a salient feature to highlight that the Birbhum District Average Yield of Linseed was higher than that of the state average in both the years of 201617 and 2017-18.

Table 5: Comparison of Yield of Crop - Linseed

\begin{tabular}{|c|c|c|c|c|c|}
\hline \multirow[b]{2}{*}{$\begin{array}{l}\text { Sl. } \\
\text { No. }\end{array}$} & \multirow[b]{2}{*}{ Year } & \multirow[b]{2}{*}{ Season } & \multicolumn{3}{|c|}{ Average Yield (q / ha) } \\
\hline & & & $\begin{array}{l}\text { Rathindra } \\
\text { KVK FLD* }\end{array}$ & $\begin{array}{l}\text { Birbhum } \\
\text { District** }\end{array}$ & $\begin{array}{l}\text { State } \\
\text { of West } \\
\text { Bengal }^{* * *}\end{array}$ \\
\hline 1 & $2015-16$ & Rabi & 06.95 & 02.40 & 03.70 \\
\hline 2 & 2016-17 & Rabi & 07.15 & 03.80 & 03.70 \\
\hline 3 & 2017-18 & Rabi & 08.12 & 02.20 & 02.10 \\
\hline
\end{tabular}

N. B.: - * Source: Annual Reports of Rathindra KVK

** and *** Source: Crop Production Statistics Information System, Special Data Dissemination Standard Division, Directorate of Economics and Statistics, Ministry of Agriculture and Farmers' Welfare, Govt. of India (Internet Source: - aps.dac.gov.in/APY/).

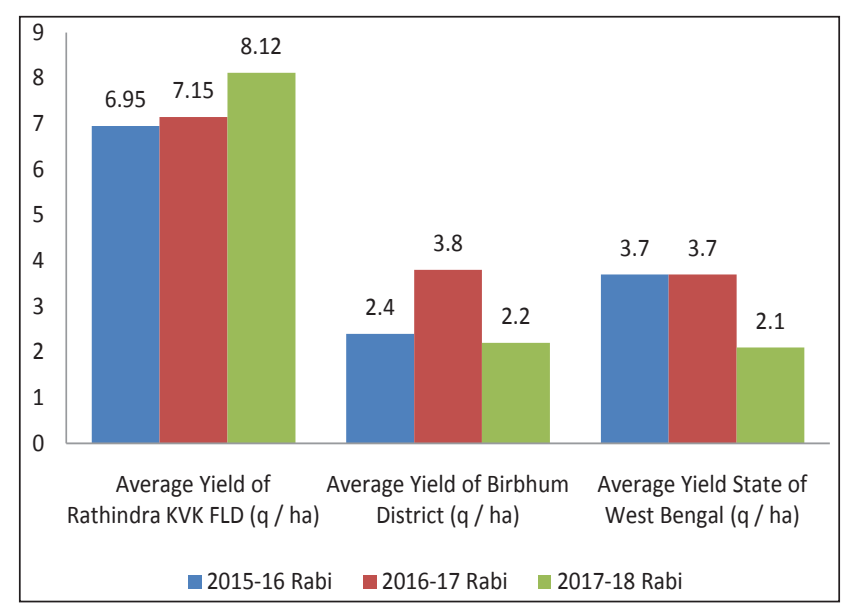

Fig. 3: Comparison of Yield of Crop - Linseed

Analysis of the Table 6 aptly revealed that the positive yield gap achieved by the Rathindra KVK FLD Programme on Linseed over Birbhum District Average Yield and at same time over the West 
Bengal State Average Yield was consistently and significantly higher in the specified time period from 2015-16 to 2017-18.

Table 6: Yield Gap of Rathindra KVK FLD Average Yield* over Birbhum District Average Yield and West

Bengal State Average Yield of Crop - Linseed

\begin{tabular}{lllll}
\hline & & & \multicolumn{2}{c}{ Yield Gap (q/ha) (+/ -) } \\
\cline { 3 - 5 } $\begin{array}{l}\text { No. } \\
\text { No. }\end{array}$ & Year & Season & $\begin{array}{l}\text { Over Birbhum } \\
\text { District Average } \\
\text { Yield }^{* *}\end{array}$ & $\begin{array}{l}\text { Over West } \\
\text { Bengal State } \\
\text { Average Yield }\end{array}$ \\
\hline 1 & $2015-16$ & Rabi & $04.55(+)$ & $03.25(+)$ \\
2 & $2016-17$ & $R a b i$ & $03.35(+)$ & $03.45(+)$ \\
3 & $2017-18$ & $R a b i$ & $05.92(+)$ & $06.02(+)$ \\
\hline
\end{tabular}

N. B.: - * Source: - Annual Reports of Rathindra KVK

** and ** Source:-Crop Production Statistics Information System, Special Data Dissemination Standard Division, Directorate of Economics and Statistics, Ministry of Agriculture and Farmers' Welfare, Govt. of India (Internet Source: - aps.dac.gov.in/APY/).

\section{CONCLUSION}

The present study helps us to arrive at certain academic points of consideration. They are as follows:

(A) The present study clearly pointed out that the FLD Programme on Sesame organized by the Rathindra KVK produced an average yield higher than the Brbhum District Average and also higher than the State Average consistently over the years i.e. from 2013 to 2017. However, here an interesting point is to note down that except the summer season of 2017, the Birbhum District average yield was consistently and significantly lower than the state Average.

Observation from the present Study clearly revealed that the FLD Programme on Rapeseed and Mustard organized by the Rathindra KVK produced consistently higher yields than both the Birbhum District Average Yield and West Bengal State Average Yield, over the specified time period i.e. from 2014-15 to 2017-18, except in the Rabi Season of 2017-18, when the State Average Yield of Rapeseed and Mustard was higher than the Average yield achieved in the Rathindra KVK FLD Progtramme. However, it is pertinent to mention that an interesting point that the
Birbhum District average yield of Rapeseed and Mustard was way below the state Average over this time frame.

The present study clearly delineated the fact that the FLD Programme on Linseed organized by the Rathindra KVK produced an average yield way higher than the Brbhum District Average as well as also significantly higher than the State Average consistently over the years i.e. from 2015-16 to 2017-18 pointing towards a huge potential in Linseed cultivation in Birbhum District as far as yield component is concerned. However, here a salient feature to highlight that the Birbhum District Average Yield of Linseed was higher than that of the state average in both the years of 2016-17 and 2017-18. So, a major point of consideration is that the Birbhum District has untapped potential (as Linseed is a minor oilseed crop of the Birbhum District with an area of only 289 hectares in 2014-15) where Linseed can be extensively grown for commercial cultivation. The choice of Linseed as a FLD Oilseed crop by the Rathindra KVK is a contextually correct initiative towards a positive direction in this regard.

(B) The present Study offered us the fact that the positive yield gap achieved by the Rathindra KVK FLD Programme on Sesame over Birbhum District Average Yield was consistently higher than the positive yield gap achieved by the FLD Programme over the state of West Bengal Average Yield over the time period of the Study i.e. from 2013 to 2017 as mentioned except for the Summer Season of 2017 where the Rathindra KVK took the initiative to introduce the crop in Birbhum District situation as a Kharif season crop.

The present study also showed us that the positive yield gap achieved by the Rathindra KVK FLD Programme on Rapeseed and Mustard over Birbhum District Average Yield was consistently higher than the positive yield gap achieved by the FLD Programme over the state of West Bengal Average Yield over the time period from 2014-15 to 201617. However, in the Rabi Season of 2017-18, though the FLD Programme gave a positive 
yield gap of impressive $2.05 \mathrm{q} /$ ha over the Birbhum District Average Yield, still the State Average Yield of Rapeseed and Mustard was slightly higher (by 0.25 q / ha) over the average yield obtained from Rathindra KVK FLD Programme.

The study further revealed that the positive yield gap achieved by the Rathindra KVK FLD Programme on Linseed over Birbhum District Average Yield and at same time over the West Bengal State Average Yield was consistently and significantly higher in the specified time period from 2015-16 to 2017-18.

(C) The stellar performance of the FLD Programme on Sesame, Rapeseed and Mustard and Linseed (organized by the Rathindra KVK) may partly be contributed through introduction of newly launched High Yielding Varieties like SWB 32-10-1 (Crop - Sesame) with a potential yield of 1.2 - 1.4 q / ha; Pusa Mahek, Pusa Bahar, NC - 1 (Crop - Rapeseed and Mustard) with yield potential of $5.97-12.65 \mathrm{q} / \mathrm{ha}$ and Sekhar, Deepika (Crop - Linseed) with potential yield of 12.72 q /ha (Govt. of India, 2020a); introduction technological package of practices like pre-emergence Herbicide application; foliar application of micronutrient sprays; optimization of irrigation application; soil testing based Integrated Nutrient Management (INM), Integrated Pest and Disease Management (IPDM) practices etc. The introduction of IPDM practices especially in the Rapeseed and Mustard Crop is one of the crucial factor for the success of the FLD Programme on this crop as Pandey et al. (2012) pointed out that the major cause of low productivity of Rapeseed and Mustard in India was the disease Alternaria Blight, which was most destructive and responsible for average yield loss of the crop up to $30-40$ per cent.

\section{REFERENCES}

Chauhan, S., Rao, V.P., Reddy, P.K., Jayasree, G.A. and Reddy, S.N. 2016. Response of sesame (Sesamum indicum L.) to irrigation scheduling based on climatological approach and $N$ fertigation levels, Journal of Oilseeds Research, 33(1): 38 - 44.
Dahama, O.P. and Bhatnagar, O.P. 1999. Education and Communication for Development, Oxford \& IBH Publishing Company Pvt. Ltd., New Delhi and Calcutta, pp. 64 of pp. 734.

Govt. of India. 2015. Study on Utilization of Rice fallows for cultivation of oilseeds and pulses in Eastern Region, Ministry of Agriculture and Farmers' Welfare, Govt. of India, New Delhi, January, pp. 4 of 6.

Govt. of India. 2016. Area Production and Productivity of Oilseeds, Directorate of Economics and Statistics, Department of Agriculture and Cooperation. Government of India, New Delhi.

Govt. of India. 2017. Area Production and Productivity of Oilseeds, Directorate of Economics and Statistics, Department of Agriculture and Cooperation. Government of India, New Delhi.

Govt. of India. 2017a. Operational Guidelines for targeting Rice-Fallow Area in Eastern India for Pulses and Oilseeds during 2017-18 to 2019-20, Oilseeds Division, Department of Agriculture, Cooperation and Farmers' Welfare, Ministry of Farmers' Welfare, Govt. of India, New Delhi, August, 2017, pp. 9 of 12.

Govt. of India. 2020. Crop Production Statistics Information System, Special Data Dissemination Standard Division, Directorate of Economics and Statistics, Ministry of Agriculture and Farmers' Welfare, Govt. of India.

Govt. of India. 2020a. http://oilseeds.dac.gov.in/Variety/Linseed. aspx, Directorate of Oilseeds Development, Ministry of Agriculture \& Farmers' Welfare, Government of India, New Delhi.

http://nmoop.gov.in/Circulars/2017-18/Cir_AllocationFunds_ TRFA_Aug2017.pdf

ICAR. 2014. Annual Report of Linseed, All India Coordinated Research Project on Linseed, Project Coordinating Unit (Linseed), Kanpur, pp 270.

ICAR. 2015. Annual Report 2014-15, All India Coordinated Research Project on Sesame, ICAR, JNKVV campus, Jabalpur.

Internet Source: -http://nmoop.gov.in/Studies/Study_Rice_ Jan_2015.pdf.

Iqbal, A., Pati, P.K., Akhtar, R., Begum, T. and Dasgupta, T. 2018. Diversity in Sesame Accessions, International Journal of Agriculture, Environment and Biotechnology, 11(5): 725 -731 .

Kithan, L. and Singh, R. 2017. Effect of nipping, crop geometry and different levels of nitrogen on the growth and yield of Sesame (Sesamum indicum L.). Journal of Pharmacognosy and Phytochemistry, 6(4): 1089 - 1092.

Pandey, D., Kumar, A., Garg, G.K., Punetha, H. and Bansal, K.C. 2012. Agrobacterium mediated transformation of Brassica juncea with Arabidopsis annexin (AnnAt1) gene, International Journal of Agriculture, Environment and Biotechnology, 5(1): $45-52$. 
